\title{
Head and Neck Cancer Clinical Regional Lymph Nodes TNM Finding v8
}

National Cancer Institute

\section{Source}

National Cancer Institute. Head and Neck Cancer Clinical Regional Lymph Nodes TNM

Finding v8. NCI Thesaurus. Code C132634.

A clinical finding about one or more characteristics of head and neck cancer, following the rules of the TNM AJCC V8 classification system as they pertain to staging of regional lymph nodes. 